\title{
The joy at the Last Judgement according to the Heidelberg Catechism Question 52
}

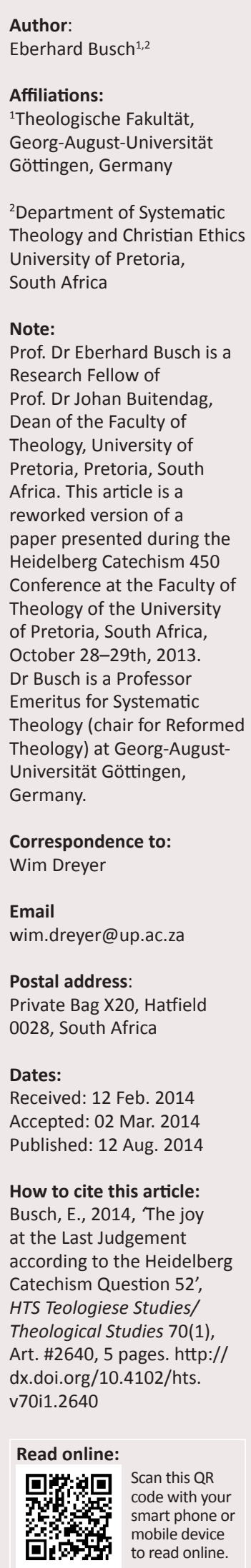

In this contribution, the author reflects on Question 52 of the Heidelberg Catechism where it asks: 'What comfort is it to you that Christ "shall come to judge the living and the dead"?' The author points out possible sources from which this formulation stems, that is, Articles 86 and 87 in John Calvin's Catechism from 1545. God is described as a compassionate judge. Even more: the One who is the last judge, was also judged and had paid for our sins. In a dialectical fashion we discover a God who is just, but also merciful. The Reformed tradition did not follow a dead-end where it is taught that God shows us grace instead of righteousness. Had God proceeded in this way, he would only mean things well, but he would not make them well. The realisation of God being just and merciful leads to joy and repentance. The contribution ends with a discussion of the final separation of the just and evil.

\section{The fundamental view of the Last Judgement}

In the traditional Roman-Catholic Mass for the deceased there is an old sequence, which is rather disturbing - the text dates back to the 13th century: 'Dies irae, dies illa, solvet saeculum in favilla ...' which translated reads as follows:

The day of wrath, that day / Will dissolve the world in ashes / As foretold by David and the Sibyl! / How much tremor there will be, / when the Judge will come, / investigating everything strictly! / [...] The written book will be brought forth, / in which all is contained, / from which the world shall be judged. / When therefore the Judge will sit, / whatever hides will appear: / nothing will remain unpunished. / What am I, miserable, then to say? / Which patron to ask, / when [even] the just may [only] hardly be sure? / King of tremendous majesty [...]

Later on, the text does at least offer some consolation: 'Thou who absolved the sinful woman, / and the dying thief forgiven, / gavest hope to me, too' (Bonn 1947:1373). However, as a whole, the Last Judgement at the end of the times is depicted in the Dies irae [Day of wrath] as a deeply frightening and terrible happening. Let us not forget though that this old sequence corresponds with words of the Prophet Zephaniah in the Old Testament: 'The great day of the Lord ... is a day of wrath' (Zephaniah 1:14).

That is why the old Reformed confessions, too, recognise that the last day of our time is nothing other than the Last Judgement, which will be decisive about all that has happened and has been done in all time. That is clear. Yet, the tone in which it is expressed in the Dies irae is unfamiliar. There is actually a sound of joy to it; joy at the coming judgement. However, this joy is not a joy because I in my own esteem believe that I have a clear conscience. The reason for the joy lies therein that the coming judgement will be the obvious victory of the righteousness of God in relation to his creation and in contrast to the mischief that had permeated it.

This comfort comes to light in the Heidelberg Catechism. Question 52 asks: 'What comfort is it to you that Christ "shall come to judge the living and the dead"?' The question itself already comes as a surprise because it does not ask 'what frightens you in the Last Judgement?', but rather 'what comfort is it to you'? The answer to it is even more surprising:

That in all my sorrows and persecutions, I, with uplifted head, look for the very One, who will come from heaven as the Judge, the same, who before offered Himself for me to the judgement of God, and removed all curse from me.

In their work the authors of the Heidelberg Catechism made use of many other catechisms; this answer is prepared in those catechisms. In the Short Catechism of the reformer in Zurich, Leo Jud, in the year 1541, the following is written: 'In the time till the return of Christ we should love one another', and 'we should get ready every day for the Lord's day that we may drive out in the air to meet Him happily, to have for ever joy with Him' (Lang et al. 
[1907] 1967:21). Similarly, Zacharias Ursinus, one of the main authors of Heidelberg Catechism (Question 103, Lang et al. [1907] 1967:167), writes in his Summa Theologiae, 'What does it mean to believe in Christ the coming judge? That means that he is maintained for to be a consolation' (author's translation from the Latin).

Closest to the Heidelberg Catechism are Articles 86 and 87 in John Calvin's Catechism from 1545, where we read:

Does it give any delight to our conscience that Christ will one day be the Judge of the world? Answer: Indeed, singular delight. For we know assuredly that He will come only for our salvation. We should not then tremble at this judgement, so as to let it fill us with dismay? Answer: No indeed since we shall only stand at the tribunal of a judge who is also our advocate, and who has taken us under his faith and protection.

The answer to Question 52 in the Heidelberg Catechism echoes those sentences to explain to what extent our judge can legally be our advocate at the same time. I repeat its decisive sentence:

That in all my sorrows and persecutions, I, with uplifted head, look for the very One, who will come from heaven as the Judge, the same, who before offered Himself for me to the judgment of God, and removed all curse from me.

The important message in this explanation is the insight that here God's behaviour is not imagined as if the once merciful saviour would appear as a strong judge at the coming Revelation. In the Heidelberg Catechism, however, it is understood that in the first coming of Christ and in his future coming the same merciful and righteous God acts: the reconciling saviour, who has given himself for us, and the earnest judge of all humans! The last future, which we are awaiting, will be the revelation of this, namely that the last judge is the solicitor who had engaged himself for our redemption and to our exoneration.

It is interesting to note here that the Catechism in Question 52 was not based on liberal inventions. As is the case with the other articles the authors gave quotes from Holy Scripture in the margin, thus indicating that the articles owe their content to statements in the Bible. In this particular case we find ten quotations. Let me list at least three of them to show that the Catechism does indeed not want to replace the reading in the Bible, but wants to help us to attain a better reading than before:

Then men will see the Son of Man coming in a cloud with great power and splendour! But when these things begin to happen, look up, hold your heads high, for you will soon be free. (Lk 21:28)

[W] wait for that redemption of our bodies which will mean that at last we have realised our full sonship in him. We were saved by this hope [...]. (Rm 8:23-24)

While we live this life we hope and wait for the glorious dénouement of the Great God and of Jesus Christ our Saviour. For he gave himself for us all, that he might rescue us from all our evil ways and make for himself a people of his own, clean and pure, with our hearts set upon living a life that is good. (Tm 2:13)
In these examples it is evident that the Catechism not only speaks by listening to the Bible, but it wants its readers to read the Bible texts, too, and perhaps to critically pose the question whether it corresponds to the teaching of the Holy Scripture.

However, the second part of the answer in the Heidelberg Catechism also reflects what had mattered to Ursinus already in both his catechisms. In the 1563 Catechism, it is stated as follows: Christ 'shall cast all His and my enemies into everlasting condemnation, but shall take me with all His chosen ones to Himself into heavenly joy and glory'. Now the question here of course is 'Why do we not have to expect the last judge at the end of all days with fear and sorrow?' Why are we allowed to look forward confidently and cheerfully, also when he will both condemn and rescue? Why do we not have to meet him with a bowed head, but may approach him with a head held high despite us being sinners, who are to be condemned because of their sins? Do we not even have to formulate why the definite decision of this judge, although it has two sides, is to be understood in the whole and not only to the one side as benevolence?

\section{The compassionate judge}

This heading does not mean that God is not judge in the full sense of the word under the assumption that he is partly or only seemingly a judge. It all becomes distorted when we do not view in a serious light the fact that he is judge, and not simply one like the judges we know for he is the last judge. Compared to him all other judges are but a weak image. He cares so profoundly about justice and righteousness that after his judgement no other or new supreme court would be necessary or possible. If at the Last judgement justice is not taken seriously and is perverted, then something like this would be justified in the worldly incidents and then the judge of this court would not be the last judge.

The biblical sense of the remission of the sin, and of God's mercy and grace does not refer to an action whereby sin and debt become harmless, but it signifies the action God takes to overcome and conquer it. Therefore, the remission of sins by God's mercy and grace does not mean that humans do not have to face the last judge who has the right to pass everlasting judgement. However, it does mean that man goes to meet the judge who, in his righteousness, is the compassionate judge and who, in this compassion is the true justified judge. It is important to understand that with 'righteousness' here is meant something that is truly right and not something that we could also perceive as unjust. What is also important though is that we have to understand the righteousness of God with regard to assessing our human justice; in other words, our righteousness has to be attuned to correspond to the righteousness of God.

We have to bear in mind that, when we hear the surprising fact that the last judge is the one who, in the words of the Catechism 'offered Himself previously for me to the judgement of God, and removed all curse from me'. Naturally, 
it does not mean that the judge here is thus dismissed because he has been uncovered as a criminal. It does not mean, either that the judge was a victim of misfortune because he had been wrongly accused and sentenced. What is meant here is that what is usually never granted indeed happens in Christ, namely that God takes care of us humans. It means that the last judge is the same as the one who had been judged on our behalf, and the one who had been judged for us is the same as the one who is our last judge. When he acts as this judge he will not have taken off his passion at the cross as an event in the past.

Whilst he had previously offered himself to the judgement of God for me, he has not reserved his call to be a judge of humans to a later time. The one who is the last judge, and the other who became judged, are the same person. He had already acted as judge with regard to our atheistic wrongness. He will always be 'the Lamb that was slain', as it is written in the book of Revelation (5:12), and in the midst of an ocean of our unrighteousness he already cared about righteousness; he did so by placing himself exactly in the place where all of us find ourselves in such wrongness and such injustice, and it is in this very place where he fought against our existence in that place. He moved us away from there; and so he alone took the whole burden of our wrong life on himself at the same time pushing away the wrongfulness and injustice. Whilst he was facing our judgement, he showed grace and charity with us. As the Catechism says, he has 'offered Himself for me to the judgement of God, and removed all curse from $m e^{\prime}$.

We understand that we do not have to separate the two, but we should not be confusing them either The Heidelberg Catechism says in Question 11: 'God is indeed merciful, but He is likewise just'. We may also turn it the other way round: he certainly is just, but He is also merciful. It belongs to the strong sides of the Reformed tradition that at this point or juncture it was mindful not to enter the dead-end that teaches that God shows us grace instead of righteousness. Should God have proceeded along this path, then he could not really have helped us humans. Then he would only mean well, but he would not make it well.

We cannot describe the doing of God by one word only. The Reformed tradition holds unto Holy Scripture in this matter. In Psalm 85:10, we hear that in the help of God 'steadfast love and faithfulness meet; righteousness and peace kiss each other'. And Psalm 116:5 says: 'Gracious is the Lord, and righteous'. In this way both sides, namely that God's grace is not a cheap grace, and His justice is not a graceless justice come together. Rather, his grace is an expensive grace, and his righteousness is a merciful reality. They are not the same, but their difference is found within in the same action of God. In this way, God makes good what we make wrong, without merely naming this good. And as much as he makes it good, he eradicates what is wrong. He says 'no' to our sins when he forgives our sins. In spite of our sins he says 'yes' to us in his grace. This 'yes' constitutes his grace, and the 'in spite', constitutes his justice.

\section{The joyful repent}

We are still on the way. We have still not reached the goal. What is awaiting us? Our end in this time, yes; but even more is to come namely the coming of Jesus Christ, or his 'coming again', as the Catechism in the German version refers to it. This means that the same one, who had already come, will come to us again: the Saviour as our judge. We fear today the consequences of what our generation is doing to God's good creation. However, what is coming at the end from God's side we do not know. We do not know what God's final decision about us will be.

What we do know with certainty is who the judge is by whose decision we will stand or fall. He is not a dark ghost of revenge who makes us fear, nor does he take the form of a disinterested decider of fate that gets a cold grip on us, for the judge is also the saviour, as the old hymn goes: 'He is just and a Helper to thee, / His power is humility, / His kingly crown is holiness, / His sceptre, pity in distress'. As he is the judge who is coming to us and to whom we walk we are allowed to trust that our wrongness and embarrassment are in good hands with him. Therefore, we may look forward in hope and confidence to the meeting with him. Therefore, we can be happy that thanks to God's mercy in our life, and in the life of nations, righteousness will prevail. In his righteousness his mercy does not disappear, but reaches its aim.

Even at this stage, this hope determines our earthly, worldly life, namely in such a way that I 'in all my sorrows and persecutions, with uplifted head', walk on my way, to quote the Catechism. The joy at the coming of the judge and saviour is not a superficial distraction to divert the attention from the present duties and difficulties and to not take them seriously, but it is the light that shines just in those duties and difficulties. This joy is not an affirmation of the fun-seeking society of today, but it is the expression of those, who 'want to be Christians earnestly', to quote Martin Luther (Herold \& Lyra 1904). This joy stems from the great relief that the last judge, according to the Catechism, has 'removed all curse from me' by his intervening on my behalf. Without that intervention life would be so hard that we would either be desperate or shallow. We do not have to live as if that help would not be given; also not when we have something to carry - namely distress and grief when a mysterious, painful fate is laid upon us, or persecution, when we are pressed by our neighbours without reason. Thanks to the great relief that is ultimately offered to us we do not have to be oppressed by that which is imposed on us, and therefore, we do not have to follow our course with a hanging head or with a shaking of heads, nor by hiding behind others but 'with uplifted head', upright, as free humans, unbroken by any power of this world, as the Catechism says.

Upright in this context does not mean having the arrogant opinion of being immaculate and having a stiff neck that prevents us from bending to those who have lost their footing. Rather, it means that in this freedom humans become free for 
the first time to do what they previously did not want to do on any account. They become free to live by the conviction that they are 'pardoned sinners', as it is said in Thesis 3 of the Theological Declaration of Barmen in 1934 - indeed pardoned, but as sinners. In the judgement of the last judge we are fully exonerated from our sin, but not from the fact that we were the persons who committed the sin. The forgiveness of the guilt is not the suppression of the guilt. The forgiveness only frees the humans from no longer having to suppress their sin. Previously, sinners in their fear of their condemnation had developed a mechanism of self-defence; that is, to push the blame out of own guilt onto other people or to suppress the guilt in our own subconscious. However, such a diversion or suppression of guilt does not rescue from it. This always leads to becoming guilty again, and it combines with the urge to gain satisfaction by accusing weaker humans and by a reinterpretation of our shortcoming in heroism. Only in the meeting with the last, the true, the gracious judge do we become free so that we do not have to either deny or supress our guilt as we used to in the past, but we are actually holding on to it. It will be a relief and liberation for us when all the hidden and suppressed nonsense will come to light once and for all and when we can at long last profess our guilt. The Swiss theologian Karl Barth said in his old-age:

This wills the judgement: There we are with our Ocean of ingratitude. And God will and wants speak: I have loved you. And then we all have to be ashamed. But please, to be ashamed in the face of the overabundance of God's grace. (Busch 2005:153)

\section{The good separation in God's judgement}

This matter is dealt with in the second part of Question 52: he 'shall cast all His and my enemies into everlasting condemnation, but shall take me with all His chosen ones to Himself into heavenly joy and glory'. How should we understand this sentence? In the Heidelberg Catechism of Ursinus, his main interest lies in the explanation of the eschatological statement of the Apostolic Creed to determine that the godless people will be condemned to an eternal punishment, whereas I, together with the elected will be admitted to the divine kingdom. This formulation reminds us of Calvin. According to him, not only the believers gain the eternal life, but only those who have been elected by God. Calvin, however, adds to this with Augustine:

$[B]$ ecause we know not who belongs to the number of the predestined, or does not belong, our desire ought to be that all may be saved; and hence every person we meet, we will desire to be with us a partaker of peace. (MSL 44:944)

Does this mean that we should be more merciful than God and that God is then more small-minded than what we are?

Perhaps this sentence should be understood conversely so that certainly all our hopes stand with the proviso of God's will, but that we should nevertheless be more broadminded than usual, because God is always far more broadminded than we are. The reformer Heinrich Bullinger in Zurich included the quoted sentence of Calvin in the second Helvetian Confession, formulated by him (Müller 1903:40-43) and he (Bullinger) at least took this sentence in the broadminded sense, referring to quotations from the Bibles in the same chapter (Müller 1903:28-34), namely: 'Come to me, all who labour and are heavy laden, and I will give you rest' (Mt 11:28), 'For God so loved the world, that he gave his only Son, that whoever believes in him should not perish but have eternal life, (Jn 3:16) and 'Your Father in heaven is not willing that any of these little ones should perish' (Mt 18:14).

However, Ursinus's idea only gently hints at what was far more strongly and at large scale professed in churches below the cross; for example, the Confession of Belgium of 1561 states that the oppressed people shall see in the Last Judgement the terrible vengeance which God shall execute on the wicked, who had most cruelly persecuted, oppressed and tormented them in this world. However they themselves, who are according to the Confession now condemned by many judges and magistrates as heretical and impious, will then be known to be the cause of the Son of God. All tears shall be wiped from their eyes and they will be crowned by God. Not less outspoken; the Scottish Confession of 1560 states:

[T]hat the time of refreshing and restitution of all things shall come, insomuch that those that from the beginning have suffered violence, injury, and wrong for righteousness' sake, shall inherit that blessed immortality [...] But contrariwise, the stubborn, disobedient, cruel oppressors, filthy persons, idolaters, and all sorts of unfaithful shall be cast in the dungeon of utter darkness, where their fire shall not be extinguished.

That is the view which has again emerged in the liberation theology nowadays. Some would have this view condemned as un-Christian. But who thinks so, should ask him- or herself, whether he or she speaks according to a Christian understanding or according to a modern desire of harmony. It is a fact that according to the Psalms or to the book of Revelation redemption is also salvation from concrete godless-inhuman enemies. According to the proverb from Madame de Staël, the grace of God is ' $[t]$ o understand all is to pardon all'. The grace of God forgives the evil in spite of the evil from which God wants it to disappear from. Here the sentence in the Old and New Testament has its legitimate place - the word of God: 'Vengeance is mine' (Rm 12:19), which means vengeance is not for us to decide but for God.

In view of the above, we may ask two questions. Firstly, does our division of the human race of released people to whom $I$ belong on the one side, and on the other side the others who are expelled not mean a prohibited anticipation of the judgement which Christ alone will execute? According to Matthew 7:1, Jesus declared: 'Be not judges of others, and you will not be judged' - to which I think, we may add: do not be a judge of yourself, either. Secondly, does that notion of the Last Judgement imply another judge than he who had offered himself to the judgement of God - for me and for our neighbours? Let us not forget what Paul wrote in 2 Corinthians 5:19: 'God was reconciling the world to himself 
in Christ, not counting men's sins against them. And he has committed to us the message of reconciliation!'

The second part of Question 52 in the Heidelberg Catechism can be understood in another way too. To be precise, the question is: who are 'the enemies of Christ' - enemies who rise against Him so that I cannot believe in Christ without seriously regarding them as my enemies too? And who really are 'my enemies'? They are those whom I have to take seriously in God's judgement only, because first the judge himself takes them seriously as his enemies who fight against his good will. If we understand the text in this strong way, then we find in Article 127 of the Heidelberg Catechism the fitting clarification. The prayer of deliverance from the evil one is formulated as a deliverance from our deadly enemies, the devil, the world, and our own flesh. If it is so, then it means that in God's Last Judgement, a separation between two groups of humans, does not take place, but a separation between the evil in all of us and the perfect liberation from the evil which is promised to all of us.

\section{Conclusion}

The Last Judgement is the hope for all humans and first for the failed, the unpleasant, and the nasty people. Then will happen what Dostoyevsky (1991) has written in Crime and punishment about a drunken father of a prostitute in a bar:

He who has pity on all men und sees all hearts, will have pity on us; he alone is Judge. At the last day he will come and say unto us: 'Ye are sots! Ye bear the mark of the beast on your foreheads, yet you come to Me.' And the wise and intelligent will say: 'Lord, Wherefore dost thou receive these?' And He will answer: 'I receive them, Oh ye wise and intelligent men, because not one of them thought himself worthy his favour.' And then He will hold out His arms, and we shall throw ourselves into them; and we shall burst into tears; and we shall understand everything. All the world will understand. Thy kingdom come. (pp. 18-19)

Maybe we have to understand the Heidelberg Catechism in the sense of what Jesus meant when He said: 'A great number, who are first, will be last, and some who are last, will be first' (Mt 19:30). This meaning resonates in the Belhar Confession (1986):

[T]hat God, in a world full of injustice and enmity, is in a special way the God of the destitute, the poor and the wronged; that God calls the church to follow Him in this, for God brings justice to the oppressed and gives bread to the hungry; that God frees the prisoner and restores sight to the blind; that God supports the downtrodden, protects the stranger, helps orphans and widows and blocks the path of the ungodly $[\ldots]$.

In Europe, where a self-centricity seems to prevail, much could be learned from the Belhar Confession.

\section{Acknowledgements Competing interests}

The author declares that he has no financial or personal relationship(s) that may have inappropriately influenced him in writing this article.

\section{References}

Augustine of Hippo, 427, Extract from Augustine's retractions, book II, Chapter 67, On the following treatise, De Corretione et Gratia, MSL 44, 944, viewed 12 February 2014, from http://www.newadvent.org/fathers/1510.html

Barth, K., 1934, Theological Declaration of Barmen, viewed n.d., from http://www. sacred-texts.com/chr/barmen.htm

Bonn, U., 1947, Das Kleine Volksmessbuch für die Sonn- und Feiertage, Einsiedeln Köln, Benziger.

Busch, E. (ed.), 2005, Karl Barth Gesamtausgabe IV, Gespräche, Gespräche 1963, Theologischer Verlag, Zürich.

Dostoyevsky, F., 1991, Crime and punishment, transl. D. McDuff, Penguin, London.

Herold, M. \& Lyra, J.W., 1904, D.M. Luthers Deutsche Messe und Ordnung des Gottesdienstes in ihren liturgischen und musikalischen Bestandteilen: Nach Gottesdienstes in ihren liturgischen und musikalischen Bestandteilen: Nach Gregorianischen Gesanges, Bertelsmann, Gütersloh.

Lang, A., Juda, L., Micronius, M. \& Ursinus, Z., [1907] 1967, Der Heidelberger Katechismus und vier verwandte Katechismen, (Leo Juds und Microns kleine Katechismen sowie die zwei Vorarbeiten Ursins), Wissenschaftliche Buchgesellschaft, Darmstadt.

Müller, E.F.K., 1903, Die Bekenntnisschriften der reformierten Kirchen, A. Deichert, Leipzig.

The Belhar Confession, 1986, viewed n.d., from https://www.rca.org/belharconfession/ Ursinus, Z., 1888, The commentary of Zacharias Ursinus on the Heidelberg catechism, transl. G.W. Williard, Elm Street Print Company, Camden. 